\title{
The Investigation on Motivation of Female College Students for Sports Activities Participation and the Countermeasure on Sport Consciousness Cultivation
}

\author{
Yanyan Chen \\ Department of Physical Education \\ Northwest University \\ Xi'an, Shaanxi, China, 710069
}

\begin{abstract}
To enhance our national physical fitness, sports activities have been valued highly. Issue on the sports activities of female college students has also attracted the attention of people. In this paper, questionnaire method, literature data method, and mathematical statistics method are used to survey the motivation of female college students as major survey object to participate in sports activities. At the same time, corresponding countermeasures for cultivating sport consciousness.
\end{abstract}

Keywords-female college students; sports activities; motivation; sport consciousness

\section{INTRODUCTION}

College students are the future of our country and pillars of the nation. With the continuous generation of new things, we have entered a new century and the sport activities of female college students have also been impacted and attracted more concerns. For female students who are gentle and soft, sports are not attractive, and competition and color of sports can not have some impact on them. Sports view of female college students is generally linked to social intercourse and entertainment. So, current college sports should fully take into account these characteristics of female college students. A good grasp of details is required on both sports facilities and teaching method to be considerate of female college students. Therefore, in this paper, a survey on motivation of female college students to participate in sports activities is made. After summary and analysis, corresponding countermeasures on how to improve their sports consciousness of female college students are proposed.

\section{ORganizATION OF THE TEXT}

\section{A. Definition of Motivation}

People have different understandings on the definition of motivation among which the meaning of motivation proposed by Abraham Harold Maslow is generally accepted. He pointed out that motivation is one of the reasons for people participating in various activities. This reason is also divided into intrinsic and extrinsic motivations. Extrinsic motivation is generated when people are under the pressure of the circumstance, while the intrinsic motivate is caused by pressure of people themselves. In the 1960s, we discussed relevant issues on motivation and pointed out that intrinsic motivation and people living environment are inextricably linked. Moreover, as for the need, it can neither be considered as people's physiological need nor be deemed as social need. On the whole, human physiological needs and psychological needs are affecting each other, and this effect is an infinite loop. After a need is satisfied, another new need will be generated, which forms a continuous cycle and constant generation of new need. People have great cultural differences while meeting the needs. Although human have the same pursuit and goal, resulting consequences are different and the methods to meet the needs are also different.

\section{B. Object and Methods of Study}

\section{1) Object of Study}

By means of questionnaire survey, totally 500 female college students in Shaanxi Province were surveyed, from different majors including liberal arts, science, medicine and so on. These 500 female college students were from 5 colleges and universities. The questionnaire survey on 500 female college students was made before the physical education class to ensure the authenticity of the questionnaire and facilitate answering and analysis if there are questions. Totally 500 questionnaires were issued and 500 are taken back. However, many survey objects indicated that they were unable to answer due to psychological motivation of sports competition, because they did not have the time and opportunity to participate in sports competitions. Therefore, the survey item was removed. Finally, 328 questionnaires were taken back.

\section{2) Methods of Study}

a) Literature data method. Issue on the participation of female college students in sports activities and sport consciousness in study is researched, and many relevant concepts are obtained.

b) Telephone interview. Teachers or leaders having experience in physical education are inquired by telephone or e-mail to learn about female college students' participation in physical exercise, and the solution is also asked. 
c) Questionnaire method. Female college students from 5 colleges and universities are surveyed through 500 questionnaires designed.

d) Mathematical statistics. Make a statistics on the survey result by SPAA11.0 to get the final result.

e) Expert interviews. Identify the authenticity and credibility of survey results via expert interviews and inquires finally.

\section{Survey Result and Analysis}

1) Psychological Motivation for Female College Students to Participate in Sports Activities

Firstly, ask physical education condition of five local colleges and visit gym teacher before investigating female college students and acquire main forms of physical education in the college and students' performance in the physical education and sports activities conditions and students' feedback to sports course and so on. It is learnt that sports courses set up in these five colleges all adopt elective system, which can arose students' motivation but most students don't interested in due to sports ground, sports facility and sports habit. Sample survey for female college students in physical education is showed in Table 1.

From extrinsic motivation column of Table 1, survey for female students' psychological motivation in physical education, the female college students who participate in sports course to acquire credits account for $61 \%$ of the total, and who participate in sports course to get scholarship account for $56 \%$ of the total, which show that female college students regard study as main work and participate in sports course in order to study. However, the female students who want to meet social requirement and acquire classmates' recognition only account for $24 \%$ and $26 \%$ respectively, which show that most female college students think that sports activities are useless after stepping into society in future and using sports activities to acquire classmates' recognition is a pessimistic thing. Meanwhile, from intrinsic motivation column of Table 1, we can see that the female college students who participate in sports activities to strengthen physique account for $58 \%$ of the total and exceed the half, which shows many female college students think that as long as they participate in sports activities, they can strengthen their physique and acquire physical health. The female college students who participate in sports activities to learn sports knowledge account for $45 \%$ of the total, which also show that female college students are interested in sports knowledge and have the motivation to understand sports consciousness. However, the female college students who participate in sports activities to improve posture and cultivate one's taste only account for $21 \%$ and $18 \%$ respectively, which show that most female students don't pay attention to their physique and they don't think that sports can improve posture and cultivate one's taste. The female students who participate in sports activities to relieve pressure account for $30 \%$, which shows that part of female students think that effect of sports to relieve pressure is very small. In general, the main functions of sports in college PE class are not accepted by female college students, while other aspects including getting scholarship and acquiring credits are main impetus to push female college students to participate in sports course and sports activities.

2) Survey Result for Psychological Motivation of Female College Students to Participate in Sports Competition

In the survey for female college students' psychological motivation to participate in sports competition, we only get 328 questionnaires because that many female college students have no time and chance to participate in sports competition. According to spot interview, many female college students think that sports competition owns to some students, and these students themselves are full of passion to sports and have excellent physical conditions. As for other type of female college students, they only participate in low-level competitions against their will. From this interview, we can see that organization of sports competition for female college students is very weak. In the 328 questionnaires, only a small portion of students participate in sports competition truly, while most students are involved in requirement. Survey result is showed in Table 2.

TABLE I. SURVEY RESUlT FOR PSYCHOLOGICAL MOTIVATION OF Female College Students in PHysical EdUCATION

\begin{tabular}{|l|l|l|l|l|l|}
\hline $\begin{array}{l}\text { Intrinsic } \\
\text { motivation }\end{array}$ & Number & Percentage & $\begin{array}{l}\text { Extrinsic } \\
\text { motivation }\end{array}$ & Number & $\begin{array}{l}\text { Percent } \\
\text { age }\end{array}$ \\
\hline $\begin{array}{l}\text { Learning sports } \\
\text { knowledge }\end{array}$ & 223 & $45 \%$ & $\begin{array}{l}\text { Strengthening } \\
\text { friendship } \\
\text { with } \\
\text { classmates }\end{array}$ & 202 & $40 \%$ \\
\hline $\begin{array}{l}\text { Improving } \\
\text { posture }\end{array}$ & 106 & $21 \%$ & $\begin{array}{l}\text { Acquiring } \\
\text { credits }\end{array}$ & 305 & $61 \%$ \\
\hline $\begin{array}{l}\text { Strengthening } \\
\text { physique }\end{array}$ & 291 & $58 \%$ & $\begin{array}{l}\text { Getting } \\
\text { scholarship }\end{array}$ & 278 & $56 \%$ \\
\hline $\begin{array}{l}\text { Cultivating } \\
\text { one's taste }\end{array}$ & 88 & $18 \%$ & $\begin{array}{l}\text { Meeting social } \\
\text { requirement }\end{array}$ & 119 & $24 \%$ \\
\hline
\end{tabular}

a. (Note: $\mathrm{N}=500$, questionnaire answers may have multiple choices)

TABLE II. SuRVEY RESUlt FOR PSYCHOLOGICAL MOTIVATION OF FEMAle College Students to PARTICIPATE IN SPORTS COMPETITION

\begin{tabular}{|l|l|l|l|l|l|}
\hline $\begin{array}{l}\text { Intrinsic } \\
\text { motivation }\end{array}$ & Number & Percentage & $\begin{array}{l}\text { Extrinsic } \\
\text { motivation }\end{array}$ & Number & Percentage \\
\hline $\begin{array}{l}\text { Realizing self } \\
\text { value }\end{array}$ & 114 & $35 \%$ & $\begin{array}{l}\text { Acquiring } \\
\text { communication } \\
\text { with classmates }\end{array}$ & 158 & $48 \%$ \\
\hline $\begin{array}{l}\text { Personal } \\
\text { interests and } \\
\text { hobbies }\end{array}$ & 239 & $73 \%$ & $\begin{array}{l}\text { Acquiring } \\
\text { communication } \\
\text { with outside } \\
\text { world }\end{array}$ & 203 & $62 \%$ \\
\hline $\begin{array}{l}\text { Cultivating } \\
\text { competition } \\
\text { awareness }\end{array}$ & 86 & $26 \%$ & $\begin{array}{l}\text { Developing } \\
\text { one's strong } \\
\text { point }\end{array}$ & 200 & $61 \%$ \\
\hline $\begin{array}{l}\text { Increasing } \\
\text { responsibility } \\
\text { sense }\end{array}$ & 99 & $30 \%$ & Winning award & 167 & $56 \%$ \\
\hline
\end{tabular}

b. $(\mathrm{N}=328$, questionnaire answers may have multiple choices) 
It can be learnt from Table 2 that extrinsic motivation in female college students' psychological motivation to participate in sports competition accounts for most basically. From extrinsic motivation, female college students who want to acquire communication with outside world account for $62 \%$, and develop one's strong point account for $61 \%$, and win award and honor in the competition account for $56 \%$ of the total, which show that extrinsic motivation is main impetus of female college students to participate in sports competition, whether to acquire communication with outside world or develop one's strong point to the limit, and become the driving force for female college students to participate in sports competition. From intrinsic motivation, female college students' interest and hobbies is the key to participate in sports competition. Personal interest and hobbies account for $73 \%$ of the total students and more than two third of female college students choose this item. As for other aspects, female college students increasing responsibility sense only account for $30 \%$ and realizing self-value only account for $35 \%$, and cultivating competition awareness only accounts for $26 \%$, which show that from another side female college students think that sports competition is useless for realizing sports self-value and cultivating competition awareness and increasing responsibility sense except for communicating with outside world and classmates and acquiring honor. In general, female college students' awareness for sports competition is relatively weak, and they can't understand lots of effects of sports competition, and surface influence of sports competition attract female college students to participate in sports competition, while female college students don't have a basic understanding of main functions of sports competition.

3) The Psychological Motivation of Female College Students to Participate in Extracurricular Sports Activities ( $N=500$, the answers may have multiple choices)

Above all, participation in physical exercise is not only in sports class, and extracurricular sports activities can even strengthen one's physique and feel exercise beauty in sports course. Extracurricular sports activities can not only strengthen female college students' physique, but also relieve their pressure in study and make more friends and expand one's communication range and enlarge one's interest and hobbies. Survey result for female college students' psychological motivation to participate in extracurricular sports activities is showed in Table 3.

TABlE III. Survey Result for Female College Students' PSYCHOLOGICAL MOTIVATION TO PARTICIPATE IN EXTRACURRICULAR SPORTS ACTIVITIES

\begin{tabular}{|l|l|l|l|l|l|}
\hline $\begin{array}{l}\text { Intrinsic } \\
\text { motivation }\end{array}$ & Number & Percentage & $\begin{array}{l}\text { Extrinsic } \\
\text { motivation }\end{array}$ & Number & Percentage \\
\hline $\begin{array}{l}\text { Acquiring } \\
\text { interest }\end{array}$ & 406 & $81 \%$ & $\begin{array}{l}\text { Broadening } \\
\text { one's horizon }\end{array}$ & 158 & $32 \%$ \\
\hline $\begin{array}{l}\text { strengthening } \\
\text { physique }\end{array}$ & 224 & $45 \%$ & Making friends & 146 & $29 \%$ \\
\hline $\begin{array}{l}\text { Honing one's } \\
\text { willpower }\end{array}$ & 412 & $82 \%$ & Self-expression & 223 & $45 \%$ \\
\hline
\end{tabular}

It can be seen from Table 3 that female college students' psychological motivation to participate in extracurricular sports activities is mainly intrinsic motivation. In intrinsic motivation, the reasons for female college students to participate in extracurricular sports activities are to acquire interest and hone one's willpower, rate of which are $81 \%$ and $82 \%$ respectively. Three fourths of female college students participate in extracurricular sports activities due to these two motivations. However, in the aspect of strengthening physique, the students only account for $45 \%$ of the total. Generally, female college students pay more attention on interest in the first place than exercising physique. However, from intrinsic motivation, we can see that no matter what reason, the amount of it is not very high. In broadening one's horizon, the students only account for $32 \%$ of the total, in making friends, number of students is even less, only accounting for $29 \%$ of the total. In self-expression, the amount of students is higher than the former two aspects, accounting for $45 \%$ of the total, but not exceeding the half of the total, which show that making friends is not the main purpose for female college students to participate in extracurricular sports activities and the female college students mainly want to acquire interest and happiness in sports activities when expressing themselves. In general, we can see from female college students' psychological motivation to participate in extracurricular sports activities that female college students don't have enough knowledge for effects of extracurricular sports activities. After entertaining themselves, they don't much understand other effects such as enlargement of friends circle and expansion of vision and these effects are not revealed in them. Therefore, extracurricular sports activity of female college students has oneness and limitation, which is an issue worthy of attention.

\section{Strategy to Cultivate Sport Consciousness}

Sports consciousness is an important element in sports, and inseparable from sports. There will be sports activities when sports consciousness exists so as to keep fit, influence the sentiment and relieve stress in learning. It plays a vital role to the future and the present.

\section{1) Continuous In-depth Understanding}

After all, physical education is a comprehensive course including psychology, physiology, mechanics and a series of courses. Its function is not just to have some sports knowledge or practice physical body, what's more, it plays an important role in human communication, social intercourse, learning, politics, literature and art. It can be seen from survey on female college students that female college students have narrow knowledge and insufficient understanding on sports so that they can not understand many features of sport and participate in class or extracurricular sports. As a result, it is needed to strengthen female college students' understanding on sports, explaining the theories, development history and features of sports to make them have more understanding on sports and go into sports.

\section{2) Change in Form of Teaching}

University physical education curriculum is more boring, which is one of the reasons why female college students do not like to participate in sports. On the basis of characteristics of 
female college students, set rich and colorful sporting events to arouse the interest of female college students. For example, add some courses on physique, body building, etc. so that female students like sports course.

\section{3) Increase of Sports Facilities}

Many colleges and universities have poor sports venues and facilities, are lack of students' favorite sports devices and sport field. Therefore, college students slowly lose the interests in sports. In order to guide female college students to participate in sports, and cultivate their interests in sports, the basic sports facilities shall be guaranteed.

4) Enhancement of Sport Consciousness of Female College Students

The enhancement of sport consciousness of female college students is the main driving force to enhance sporting behavior and not relies only on teachers. Continue to carry out sports activities, and develop multilevel and multi-angle sports so as to gradually promote sports awareness of female college students.

\section{CONCLUSION}

In continuous strengthening of sports cause, sport consciousness of female college students shall be brought to the forefront. We can see that there are many problems existing through survey on motivation and sport consciousness of female college students to participate in sports, including lack of sports knowledge of female college students, incomprehension on features of sports, which makes female college students gradually lose interest in sports source and sports activities. Certain measures must be taken to promote female college students to actively participate in sports, such as change in course and sport field, addition of sports facilities. Only when female college students are truly participated in sports activities and have sport consciousness and develop an affinity for sports, overall physical quality of Chinese citizens will be raised.

\section{REFERENCES}

[1] Gao Lan. Investigation on Motivation of Shandong Female College Students for Participation in Sports Activities and Countermeasure to Cultivate Sport [J]. Technology Forum, 2010 (35).

[2] Niu Ling. Investigation on Sport Consciousness and Current Situation of Regular College Students [J]. Zhongzhou University Journal, 2002 (1).

[3] Zhang Yong. Research on Analysis of Chongqing Female Collage Students' Sports Behavior Characteristics and Promotion Strategies [J]. Chongqing University, 2007 (4). 